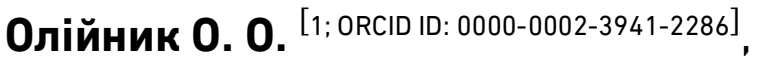
к.е.н., доцент

${ }^{1}$ Національний університет водного господарства та природокористування, м. Рівне

\title{
СОЦІАЛЬНИЙ КАПІТАЛ В КОНТЕКСТІ СОЦІАЛЬНОЇ ВІДПОВІДАЛЬНОСТІ ПІДПРИЕМСТВ
}

В статті досліджено можливості використання соціальної відповідальності в якості інструменту формування соціального капіталу підприємств. Визначено, що корпоративні зусилля 3 формування та розвитку соціального капіталу належать до сфери соціальної відповідальності підприємств. Проаналізовано інструменти налагодження взаємодії із ключовими стейкхолдерами окремих суб'єктів господарювання в Україні.

Ключові слова: соціальний капітал; соціальна відповідальність; підприємство; взаємодія; соціальна мережа; довіра; соціальні норми; цінності.

Постановка проблеми. В епоху становлення соціальної економіки в Україні все більшої популярності в наукових та ділових колах набувають новітні концепції корпоративного управління: соціальна відповідальність, соціальна згуртованість, соціальний капітал тощо. Соціальна складова діяльності підприємств набуває особливої актуальності під час кризи, викликаної пандемією COVID19. Зміна форм зайнятості, а відтак і соціалізації працівників, суттєво впливає на дотримання соціальних норм та цінностей, здійснення внутрішніх та зовнішніх комунікацій, формування корпоративної культури, процеси найму та звільнення, розвитку персоналу тощо. За таких умов виникає необхідність в дослідженні можливостей формування соціального капіталу як системи соціальних відносин через призму соціальної відповідальності підприємств задля забезпечення їхньої стійкої конкурентоспроможності.

Аналіз останніх досліджень та публікацій. Дослідженню проблематики соціального капіталу та соціальної відповідальності присвятили свої наукові публікації вітчизняні та зарубіжні науковці, зокрема: Д. Баюра, О.Грішнова, О. Лучик, В. Надрага, А. Колот, 0. Охріменко, О. Попадюк, О.Руденок, О.Степанова, С. Філиппова, Ф. Фукуяма та ін. Однак, незважаючи на значну увагу науковців та практиків до дослідження соціальної складової діяльності 
підприємств, формування ефективної системи налагодження соціальних відносин з ключовими зацікавленими сторонами, здатної швидко адаптуватись до зовнішніх та внутрішніх трансформацій, не набуло широкого поширення в бізнес-діяльності вітчизняних підприємств. Відтак дослідження взаємозв'язку соціального капіталу та соціальної відповідальності підприємств $€$ актуальним науковим завданням.

Метою роботи $\epsilon$ дослідження можливостей використання соціальної відповідальності як інструменту формування соціального капіталу підприємств.

Виклад основного матеріалу. Концепція соціального капіталу почала активно розвиватись відносно недавно. Однак, цей термін використовується теоретиками та практиками вже більше століття. Чи не вперше категорія «соціальний капітал» з'явилась в книзі Л. Ганіфан в 1916 р. в США в аспекті взаємодії між сусідами щодо нагляду за школами.

Соціальний капітал - це сукупність зв'язків та соціальноекономічних відносин, здатних приносити дохід, які виникають у певній соціальній мережі на основі існуючих норм та довіри [1]. Соціальний капітал визначається як суспільні активи, які допомагають підвищувати ефективність господарської діяльності.

Соціальний капітал - складне та багатоаспектне явище, в якому можна виділити три ключові елементи:

1) соціальні мережі - взаємодія та стосунки між окремими людьми або організаціями;

2) довіра та взаємність, які стосуються якості відносин, а не кількості зв' язків;

3) спільні норми та цінності - загальні очікування, які роблять взаємодію більш продуктивною [2].

На основі аналізу сучасних концепцій щодо трактування сутності, структури та підходів до формування соціального капіталу, можна виокремити такі його основні характеристики:

- соціальний капітал виступає однією 3 форм капіталу підприємства поруч 3 людським, фізичним, фінансовим, інтелектуальним тощо;

- соціальний капітал має нематеріальну основу;

- підґрунтям формування соціального капіталу $€$ сукупність етичних норм, соціальна згуртованість, соціальні зв'язки та взаємодії, довіра;

- соціальний капітал покликаний виконувати різноманітні функції;

- важливою ознакою соціального капіталу $є$ низький рівень 
його формалізації;

- соціальний капітал $€$ продуктивним, оскільки надає підприємству можливість отримувати конкурентні переваги та досягати поставлених цілей;

- за умови недостатнього використання соціального капіталу його обсяг зменшується [3].

Таким чином, соціальний капітал $\epsilon$ відображенням індивідуальних та громадських мереж. Такі мережі можуть характеризуватись достатньо міцними або досить слабкими зв'язками. Міцні зв'язки формуються між людьми або організаціями з сімейною, трудовою чи професійною історією. Саме завдяки цим зв'язкам формується високий рівень довіри, відтак члени такої мережі готові ділитися детальною інформацією, вони більш схильні до співпраці. Слабкі ж зв'язки виникають при взаємодії у різних контекстах чи економічних кластерах, де контакти $€$ часто спорадичними. Водночас ці зв'язки забезпечують доступ до нової інформації та нових знайомств за межами існуючих мереж.

На корпоративному рівні соціальні відносини можуть існувати всередині організації (наприклад, між працівниками) та поза організацією (наприклад, між організацією та зовнішніми зацікавленими сторонами, такими як споживачі, місцева громада, громадські організації, бізнес-партнери, органи державної влади та місцевого самоврядування тощо).

Соціальний капітал важливий для кожного підприємства, яке хоче досягти високих цілей в найкоротші терміни. Якщо розглядати корпоративну структуру як команду, то в ній кожен член має свою роль, виконуючи яку на належному рівні, сприяє добробуту всієї структури. Такий організаційний підхід видаляє поняття «Я» 3 підприємства та зосереджується на категорії «Ми», оскільки «якщо я зроблю свій внесок у благополуччя своїх колег, вони будуть робити те саме, і всі ми отримаємо від цього вигоду». Якщо підприємство володіє величезним соціальним капіталом, то таке мислення виникає природно [4].

Соціальний капітал - це ресурси, знання та інформація, які накопичуються окремою особою, організацією чи колективом у результаті створення мережі соціальних відносин всередині підприємства або між підприємствами. Для створення соціального капіталу необхідно:

- встановити зв'язки та мережеві відносини 3 ключовими зацікавленими сторонами, такими як працівники, клієнти, 
постачальники, конкуренти, ділові партнери, місцеві громади, а також представники держаної та місцевої влади;

- розвивати довіру з ключовими зацікавленими сторонами;

- розробити спільні норми, спільні цінності та цілі, щоб вплинути на ставлення та поведінку стейкхолдерів;

- отримати та зберепи соціальну ліцензію на діяльність, щоб продемонструвати свою прихильність до ключових зацікавлених сторін [5].

Можна стверджувати, що корпоративні зусилля з формування та розвитку соціального капіталу належать до сфери соціальної відповідальності підприємств, оскільки діалог із зацікавленими сторонами є одним із семи принципів соціальної відповідальності (дотримання норм і прав людини, добровільність, постійність, прозорість, підзвітність, етична поведінка). Ці принципи виписані в Міжнародному стандарті ISO 26000 «Керівництво 3 соціальної відповідальності» [6]. Згідно даного документу діалог із зацікавленими сторонами передбачає надання інформації та роз'яснення рішень, намірів та пріоритетів в сфері соціальної відповідальності. При цьому такий діалог повинен відбуватись на засадах повної інформаційної відкритості.

Водночас принцип партнерства підприємств із зацікавленими сторонами слід поглиблювати за рахунок специфічних принципів соціальної відповідальності для забезпечення синергетичного ефекту від соціально відповідальних програм:

- перехід від добровільних ініціатив до обов'язкової практики соціальної відповідальності для всіх суб'єктів господарювання;

- готовності до постійного діалогу зі стейкхолдерами задля недопущення конфліктних ситуацій;

- створення принципово нових підходів до ведення бізнесу, створення продукту, технологій, методів управління персоналом тощо, що забезпечить реалізацію цілей сталого розвитку суспільства і подолання його викликів;

- доброчесності (передбачає сумлінну, чесну, відкриту діяльність підприємства щодо всіх стейкхолдерів і суспільства) [7].

Практика налагодження взаємовідносин підприємств із своїми зацікавленими сторонами в Україні різниться залежно від усвідомлення важливості дотримання соціально відповідальних принципів в бізнес-діяльності, організаційного, фінансового та нормативно-правового забезпечення реалізації соціальної відповідальності на підприємстві. Перелік інструментів налагодження взаємодії із ключовими стейкхолдерами окремих суб'єктів господарювання в Україні наведено в табл. 1. 
Інструменти взаємодії із зацікавленими сторонами

Суб'єкт господарювання Компанія «Нібулон»

Агропромхолдинг «Астарта-Київ»

Компанія «Делойт» в Україні

Компанія «SoftServe»

Інструменти телеканали регулярні зустрічі з місцевою громадою дзвінки, листування
Зустрічі, засідання, круглі столи, конференції, ознайомлювальні екскурсії по підприємству, корпоративний сайт, регіональні та всеукраїнські друковані видання (газети, журнали), інтернет-видання,

Щорічні та періодичні звіти, зустрічі, презентації, корпоративний сайт, участь у конференціях, публікації в 3МІ та соціальних мережах, офіційне листування, тематичні семінари, корпоративні заходи, корпоративні публікації, анкети, колективні договори, кодекс корпоративної етики, тренінги, консультації, «гаряча лінія», анкетування, інтерв'ю, соціальні та благодійні програми, друковані матеріали (плакати, буклети),

Зустрічі, річна спільна зустріч з презентацією результатів і планів компанії, дорадчі ради, програми навчання й розвитку, коучинг, встановлення цілей та оцінювання результатів, зворотний зв'язок щодо роботи, тижні цінностей, етики, безпеки, well-being-програма, корпоративне волонтерство, звернення до лідера 3 питань бізнес-етики, соціальні медіа, рекрутингові події, освітні програми й курси для студентів, стажування, інтерв'ю у разі звільнення, спільнота Deloitte Alumni, взаємодія в межах виконання проєктів, опитування задоволеності клієнтів, конференції та освітні заходи, регіональні, глобальні зустрічі керівництва, конференц-

Вебсайт, соціальні мережі, бізнес-події, опитування, листування, пряма взаємодія, конференції, тематичні заходи, зустрічі, внутрішня соціальна мережа Workplace, дослідження задоволеності працівників (eSAT), діалог між менеджером і працівником, корпоративні свята, внутрішні заходи тощо

Джерело: складено за даними [8; 9; 10; 11].

В епоху інформатизації всіх сфер суспільного життя підприємства до сить активно та широко використовуються різноманітні інформаційні системи та технології задля налагодження ефективної взаємодії із своїми ключовими стейкхолдерами. Так, задля стейкхолдерів на офіційному сайті компанії «Нібулон» створено розділи «Контактна інформація для інвесторів» та «Інформація для стейкхолдерів компанії». У 2012-2013 роках створено окремі розділи та рубрики на корпоративній вебсторінці компанії, де висвітлюються різноманітні аспекти екологічної i 
соціальної складової стійкого розвитку, а саме: «Корпоративна соціальна відповідальність» та «Інвестиційна діяльність». Завдяки такому підходу зусилля компанії щодо забезпечення достатньої інформованості всіх зацікавлених сторін допомагають уникати інформаційного вакууму щодо господарської діяльності та загрози виникнення інформаційної кризи. У разі появи недостовірної інформації про діяльність компанії, відповідальні особи оперативно реагують, розміщуючи на корпоративному сайті, у регіональних і всеукраїнських друкованих та інтернет-виданнях аргументоване професійне спростування [8].

Сьогодні підприємства визнають, що залежать від зацікавлених сторін, і завдяки постійному вдосконаленню сталої бізнес-практики мають можливість строювати цінності для всіх стейкхолдерів, вступаючи в діалог та партнерські відносини для подальшого розвитку соціально відповідальної ділової діяльності.

Висновки. Таким чином, реалізація соціальної відповідальності $€$ важливим інструментом формування соціального капіталу підприємства. Саме завдяки дотримання принципів цієї концепції створюються умови для ефективної взаємодії як з внутрішніми, так і з зовнішніми стейкхолдерами. Як наслідок, підприємство отримує суттєві конкурентні переваги, основними з яких є:

- завоювання нових ринків збуту продукції;

- зниження трансакційних витрат;

- формування нових партнерств для вирішення актуальних соціальних та екологічних проблем;

- покращення лояльності ключових стейкхолдерів;

- ефективне вирішення можливих конфліктних ситуацій із зацікавленими сторонами;

- розвиток корпоративної культури тощо.

1.Грицаєнко М.І. Сутність соціального капіталу та його особливості в аграрній сфері. Економіка АПК. 2018. № 1. С.60-65. 2. Executive Report: Measuring and Valuing Social Capital. Network for business sustaiability. URL: https://www.nbs.net/articles/executive-report-measuring-and-valuing-social-capital (дата звернення: 10.04.2021). 3. Гриненко А. М., Кирилюк В. В. Соціальний капітал: сутність та генезис його трактування. Соціально-трудові відносини: теорія та практика. 2017. № 2. С. 321-328. 4. Successful Organizations Run on Social Capital. Kanbanize. URL: https://kanbanize.com/blog/successful-organizations-run-on-socialcapital/ (дата звернення: 10.04.2021). 5. Acquaah M., Amoako-Gyampah K., Gray B., Nyathi N. Q. Measuring and Valuing Social Capital: A Systematic Review. Network for Business Sustainability South Africa. 2014. URL: https://static1.squarespace.com/static/5d5156083138fd000193c11a/t/5f2f7af40c199 16a42632eb2/1596947240444/NBS-SA-Social-Capital-SR.pdf (дата звернення: 10.04.2021). 6. Guidance on social responsibility. ISO 26000. ISO. URL: https://iso26000.info/wp-content/uploads/2017/06/ISO- 
26000_2010_E_OBPpages.pdf (дата звернення: 10.04.2021). 7. Попадюк 0. В., Лучик О.І. Принципи та механізм соціальної відповідальності в умовах стратегічного управління підприємством. Інфраструктура ринку. 2019. № 36. С. 235246. 8. Соціальний звіт 2018-2019. Компанія Нібулон. URL: https://nibulon.com/uploads/files/site_tree/104/1105.pdf (дата звернення: 10.04.2021). 9. Звіт зі сталого розвитку 2020. Агропромхолдинг Астарта-Київ. URL: https://astartaholding.com/files/uploads/446e32f063f3788870df1cf9e8dbf48c.pdf (дата звернення: 10.04.2021). 10. Звіт зі сталого розвитку компанії «Делойт» в Україні 2019-2020. Компанія «Делойт в Україні». URL: https://www2.deloitte.com/ua/uk/pages/press-room/press-release/2021/deloitteukraine-sustainable-development-report.html (дата звернення: 10.04.2021). 11. Звіт з корпоративної соціальної відповідальності за 2017-2018 pp. SoftServe. URL: http://svb.ua/sites/default/files/softserve-social-responsibility-report-2017-2018ua.pdf (дата звернення: 10.04.2021).

\section{REFERENCES:}

1. Hrytsaienko M. I. Sutnist sotsialnoho kapitalu ta yoho osoblyvosti v ahrarnii sferi. Ekonomika APK. 2018. № 1. S. 60-65. 2. Executive Report: Measuring and Valuing Social Capital. Network for business sustaiability. URL: https://www.nbs.net/articles/executive-report-measuring-and-valuing-social-capital (data zvernennia: 10.04.2021). 3. Hrynenko A. M., Kyryliuk V. V. Sotsialnyi kapital: sutnist ta henezys yoho traktuvannia. Sotsialno-trudovi vidnosyny: teoriia ta praktyka. 2017. № 2. S. 321-328. 4. Successful Organizations Run on Social Capital. Kanbanize. URL: https://kanbanize.com/blog/successful-organizations-run-on-social-capital/ (data zvernennia: 10.04.2021). 5. Acquaah M., Amoako-Gyampah K., Gray B., Nyathi N. Q. Measuring and Valuing Social Capital: A Systematic Review. Network for Business Sustainability South Africa. $2014 . \quad$ URL: https://static1.squarespace.com/static/5d5156083138fd000193c11a/t/5f2f7af40c199 16a42632eb2/1596947240444/NBS-SA-Social-Capital-SR.pdf (data zvernennia: 10.04.2021). 6. Guidance on social responsibility. ISO 26000. ISO. URL: https://iso26000.info/wp-content/uploads/2017/06/ISO-

26000_2010_E_OBPpages.pdf (data zvernennia: 10.04.2021). 7. Popadiuk 0. V., Luchyk 0. I. Pryntsypy ta mekhanizm sotsialnoi vidpovidalnosti $v$ umovakh stratehichnoho upravlinnia pidpryiemstvom. Infrastruktura rynku. 2019. № 36. C. 235246. 8. Sotsialnyi zvit 2018-2019. Kompaniia Nibulon. URL: https://nibulon.com/uploads/files/site_tree/104/1105.pdf (data zvernennia: 10.04.2021). 9. Zvit zi staloho rozvytku 2020. Ahropromkholdynh Astarta-Kyiv. URL: https://astartaholding.com/files/uploads/446e32f063f3788870df1cf9e8dbf48c.pdf (data zvernennia: 10.04.2021). 10. Zvit zi staloho rozvytku kompanii «Deloit» v Ukraini 2019-2020. Kompaniia «Deloit v Ukraini». URL: https://www2.deloitte.com/ua/uk/pages/press-room/press-release/2021/deloitteukraine-sustainable-development-report.html (data zvernennia: 10.04.2021). 11. Zvit z korporatyvnoi sotsialnoi vidpovidalnosti za 2017-2018 rr. SoftServe. URL: http://svb.ua/sites/default/files/softserve-social-responsibility-report-2017-2018ua.pdf (data zvernennia: 10.04.2021). 


\section{SOCIAL CAPITAL IN THE CONTEXT OF SOCIAL RESPONSIBILITY OF ENTERPRISES}

This article explores the possibilities of using social responsibility as a tool for the formation of social capital of enterprises. The essence of the category «social capital», its main components (social networks, trust and reciprocity, common norms and values) are defined. Based on the analysis of modern concepts regarding the interpretation of the essence, structure and approaches to the formation of social capital, its main characteristics are determined. Differences between individual and public networks with rather strong and rather weak connections are revealed. It is determined that corporate efforts to form and develop social capital belong to the sphere of social responsibility of enterprises, as dialogue with stakeholders is one of seven principles of social responsibility. Dialogue with stakeholders involves providing information and explaining decisions, intentions and priorities in the field of social responsibility. At the same time, such a dialogue should take place on the basis of full information openness. The tools of establishing interaction with key stakeholders of certain business entities in Ukraine are analysed. It is proved that due to the principles of the concept of social responsibility conditions are created for effective interaction with both internal and external stakeholders, the establishment of stable social relationships.

Keywords: social capital; social responsibility; enterprise; interaction; social network; trust; social norms; values.

Олейник Е. А. [1; ORCID ID: 0000-0002-3941-2286], к.э.н., доцент

${ }^{1}$ Национальный университет водного хозяйства и природопользования, г. Ровно

\section{СОЦИАЛЬНЫЙ КАПИТАЛ В КОНТЕКСТЕ СОЦИАЛЬНОЙ ОТВЕТСТВЕННОСТИ ПРЕДПРИЯТИЙ}

В статье исследованы возможности использования социальной ответственности как инструмента формирования социального капитала предприятий. Определено, что корпоративные усилия по формированию и развитию социального капитала относятся к сфере социальной 
ответственности предприятий. Проанализированы инструменты налаживания взаимодействия с ключевыми стейкхолдерами отдельных субъектов хозяйствования в Украине.

Ключевые слова: социальный капитал; социальная ответственность; предприятие; взаимодействие; социальная сеть; доверие; социальные нормы; ценности.

Отримано: 28 квітня 2021 р. Прорецензовано: 02 травня 2021 р. Прийнято до друку: 25 червня 2021 р. 